\title{
Comparative study of the healing process of the aponeurosis of the anterior abdominal wall of rats after wound closure using 3-0 nylon suture and N-butil-2-cyanoacrylate tissue adhesive ${ }^{1}$
}

\author{
Estudo comparativo da cicatrização da aponeurose da parede abdominal anterior com a utilização \\ do fio de poliamida monofilamentar 3-0 e o adesivo N-Butil-2-Cianoacrilato em ratos
}

\author{
Carlos Augusto Marques BatistaI, Ramiro Colleoni NetoII, Gaspar de Jesus Lopes FilhoIII \\ ${ }^{\text {I }}$ Full Professor of Surgery of the School of Medicine of Valença, Rio de Janeiro, Brazil. \\ II Affiliate Professor of Surgical Gastroenterology, School of Medicine, Federal University of São Paulo (UNIFESP), Brazil. \\ ${ }^{\text {III }}$ Associate Professor and Head, Division of Surgical Gastroenterology, Department of Surgery, School of Medicine, UNIFESP, São Paulo, \\ Brazil.
}

\begin{abstract}
Purpose: To investigate the healing process of the aponeurosis of the anterior abdominal wall of rats, comparing two different materials for wound closure: 3-0 nylon suture and tissue adhesive N-butyl-2-cyanoacrylate. Methods: Forty-four Wistar rats were randomly divided into four groups according to the type of material used (suture or adhesive) and the number of days until reoperation (seven or 14 days). After a $4 \mathrm{~cm}$ incision in the aponeurosis, 22 rats underwent wound closure using 3-0 nylon suture and the other 22, the tissue adhesive. After seven days, 11 rats from each group were weighed again, submitted to reoperation and then euthanized. The same procedure was carried out after 14 days with the remaining rats. The surgical wound was macroscopically examined, the tensile strength was measured and the tissue edges were histologically examined. The statistical analysis was performed using analysis of variance and Cox's proportional hazards model. Significance level was set at $p<0.05$. Results: The animals lost on average $20 \mathrm{~g}$ over the period between the two operations. Wound closure was faster using the tissue adhesive. Only one animal, from the tissue adhesive group, had a small abscess with wound dehiscence. With regard to tensile strength, the best results were obtained with the tissue adhesive 14 days after the first surgery. The results of the histological examination showed no significant difference between groups. Conclusions: Upon morphological evaluation, the two types of material analyzed in this study (3-0 nylon suture and N-butyl-2-cyanoacrylate, a tissue adhesive) were not significantly different with regard to the healing process of the aponeurosis of the anterior abdominal wall of rats. Wound closure using the tissue adhesive was faster. Higher tensile strength was observed in the tissue adhesive group 14 days after the first surgery.
\end{abstract}

Key words: Suture Techniques. Wound Healing. Cyanoacrylate. Abdominal wall. Aponeurosis. Rats.

\section{RESUMO}

Objetivo: Investigar o processo de cicatrização da aponeurose da parede abdominal anterior em ratos, comparando dois diferentes materiais de sutura: fio de poliamida monofilamentar 3-0 e adesivo N-butil-2-cianoacrilato. Métodos: Quarenta e quatro ratos Wistar, foram divididos aleatoriamente em quatro grupos, de acordo com o material de síntese (fio e adesivo cirúrgico) e o tempo de reoperação (7 e 14 dias). Após uma incisão de $4 \mathrm{~cm}$ na aponeurose, 22 animais foram submetidos à síntese com o fío de poliamida e os outros 22 animais com o adesivo proposto. Após o procedimento, aguardou-se um período de 7 e 14 dias, quando os animais, 11 de cada grupo, foram novamente pesados e submetidos à eutanásia, sendo realizada a avaliação macroscópica da ferida operatória, mensuração da força de ruptura da parede abdominal e estudo histológico das bordas da incisão. A análise estatística foi realizada através de um modelo de análise de variância e de riscos proporcionais de Cox, considerando significantes valores de $\mathrm{p}<0,05$. Resultados: Os animais apresentaram uma perda média de $20 \mathrm{~g}$, do dia da operação para o dia da reoperação. A síntese da aponeurose com o adesivo tecidual foi o método mais rápido. Apenas um animal, do grupo adesivo tecidual, apresentou pequeno abscesso local com deiscência de sutura. Com relação à força de ruptura da aponeurose, o melhor desempenho foi do grupo adesivo tecidual, com 14 dias de pós-operatório. Quanto ao estudo histológico, os resultados não mostraram diferença estatisticamente significante entre os dois grupos. Conclusões: $\mathrm{O}$ estudo do processo de cicatrização da aponeurose da parede abdominal anterior mostrou que tanto a síntese com o adesivo N-butil-2-cianoacrilato como com o fio de poliamida monofilamentar 3-0 não apresentou diferença estatisticamente significante na avaliação morfológica, enquanto que a síntese com o adesivo foi mais rápida e mais resistente ao teste de força de ruptura no $14^{\circ}$ dia do que a síntese com o fio.

Descritores: Técnicas de Sutura. Cicatrização de Feridas. Cianoacrilato. Parede abdominal. Aponeurose. Ratos.

${ }^{1}$ Research performed at the Laboratory of Surgery of the School of Medicine of Valença, Brazil. Abstract of the Master's thesis presented at the Post-Graduate Program in Surgical Gastroenterology of the School of Medicine, Federal University of São Paulo (UNIFESP), Brazil. 


\section{Introduction}

The aponeurosis is a laminar structure whose function is to support forces, keeping body segments in position. The histological structure of the aponeurosis consists of fibrous tissue, mainly collagen with a small amount of extracellular matrix and cells, which gives this structure strength and little elasticity $^{1}$.

The abdominal wall is the entry point for all surgical procedures in the abdominal cavity and for some in the retroperitoneum ${ }^{2}$. The closure of the abdominal wall is a common but important procedure, one of the first a surgeon is taught to perform. The surgeon has to choose a mechanical means of keeping the abdominal wall closed until the healing process is complete and strong enough to keep the surgical wound closed $^{2,3,4,5}$.

It can certainly be said that the opening and closure of the abdominal wall are some of the most common procedures in the daily practice of surgery ${ }^{2}$.The wide variety of materials and techniques for the closure of the abdominal wall shows the concern of surgeons with the subject ${ }^{2,3,5}$. The sheer volume of surgical literature on the topic reveals the lack of consensus regarding the ideal suturing technique for the closure of the abdominal wall ${ }^{3,5,6}$.

Even with the development of minimally invasive surgery, the ideal closure of the abdominal wall remains a priority $^{2}$. Successful closure of the abdominal wall should restore its shape and function after a surgical intervention, and prevent possible complications. It should be comfortable for the patient and leave an esthetically acceptable scar ${ }^{2,3,4,7,8}$.

Cyanoacrylates were first synthesized by Ardis in $1949^{5,9}$, and have been successfully used for various purposes because of their good adhesive properties. The original compound was a cyanoacrylic acid methyl ester, Eastman 910 Monomer Adhesive, developed in 1951 by the Eastman Kodak Laboratory. Its application in Medicine and the interest in its surgical use date back to $1960^{5,9,10,11,12}$.

The possibility of using an adhesive substance that can make the closure of different tissues simpler, faster and more efficient is an appealing idea that has drawn the attention of surgeons ${ }^{10,11,13}$.

Since the beginning of the 1960s, studies have investigated the use of cynoacrylates in Medicine, Dentistry and Veterinary Medicine for tissue closure, suture support and hemostasia, among others. The results obtained so far are encouraging, especially because the procedure is quick and the cost is low lo, $^{5,10,11,13}$. Many comparative studies that investigate the best method of closing the abdominal wall are found in the literature ${ }^{2,3,6,8}$. Some studies have compared the use of sutures and adhesives, both in the skin ${ }^{5,11,13}$ and in the aponeurosis, for the fixation of the Marlex ${ }^{\circledR}$ mesh in hernia repair ${ }^{14}$.

There is still disagreement in the literature over the best method for closing the abdominal wall. Many studies, with different samples and means of assessment, have reported advantages of this or that technique over the others, or rather, have concluded that different techniques yielded similar results ${ }^{2,6}$. In addition, among the numerous studies of the healing process found in the literature, few have exclusively investigated the healing process of the aponeurosis ${ }^{1}$.

The purpose of this study was to experimentally investigate the healing process of the aponeurosis of the anterior abdominal wall of rats, comparing two different materials for wound closure: 3-0 monofilament nylon suture and N-butyl-2cyanoacrylate, a tissue adhesive. The two materials were assessed considering the time taken to close the surgical wound, tensile strength and morphological evaluation of the site.

\section{Methods}

The research was performed at the Laboratory of Experimental Surgery of the Department of Surgery, School of Medicine, Valença, Brazil.

The adhesive used in this study was N-butyl-2-cyanoacrylate, commercially known as Histoacryl ${ }^{\circledR}$.

Forty-four male Wistar rats weighing between 250 and $400 \mathrm{~g}$, previously treated and vaccinated, were used in this study. The rats were donated by the laboratory animal facility of the School of Veterinary Medicine, Valença, Brazil. They were kept under natural light conditions and room temperature, and were given water and food suitable for the species. The rats were randomly divided into two groups of 22 animals each, according to the method used for wound closure: group I - suture and group II - tissue adhesive.

The surgical procedures were performed in accordance with international guidelines for animal experimentation ${ }^{15}$. The rats underwent general anesthesia with sodium thiopental $(2.5 \%$ - dose of $50 \mathrm{mg} / \mathrm{kg})$ intraperitoneally administered to the right lower quadrant ${ }^{2,6,7}$. Depending on whether it was necessary to keep the animals anesthetized, each subsequent dose administered was half of the initial one. The rats were kept under mechanical ventilation for the duration of the anesthetic and surgical procedures.

The animals were then placed on a board in the supine position, and restrained with string. Povidone-iodine at $2 \%$ was applied to the abdominal region after shaving using a disposable razorblade. The surgical field was created using a sterile drape to isolate the disinfected area from surrounding areas.

A paramedian incision of $4 \mathrm{~cm}$ was made in the right upper abdominal wall, without opening the peritoneum. In group I animals, the aponeurosis was sutured using 3-0 monofilament nylon suture and a simple continuous suture technique (Figure 1). The skin was sutured using 4-0 monofilament nylon suture and a simple continuous suture technique (Figure 2). In group II animals, the wound edges were brought together with 3-0 linen suture, and then the surgical wound was closed with a uniformly thin layer of adhesive $e^{5,9}$. The skin was sutured using 4-0 monofilament nylon suture and a simple continuous suture technique (Figure 3). The time required to close the aponeurosis was recorded. In group I, the time count began when the threaded needle was first inserted into the aponeurosis, and was interrupted when the nylon suture was cut after the final knot. In group II, the time required to apply the adhesive to the surgical wound was recorded. 


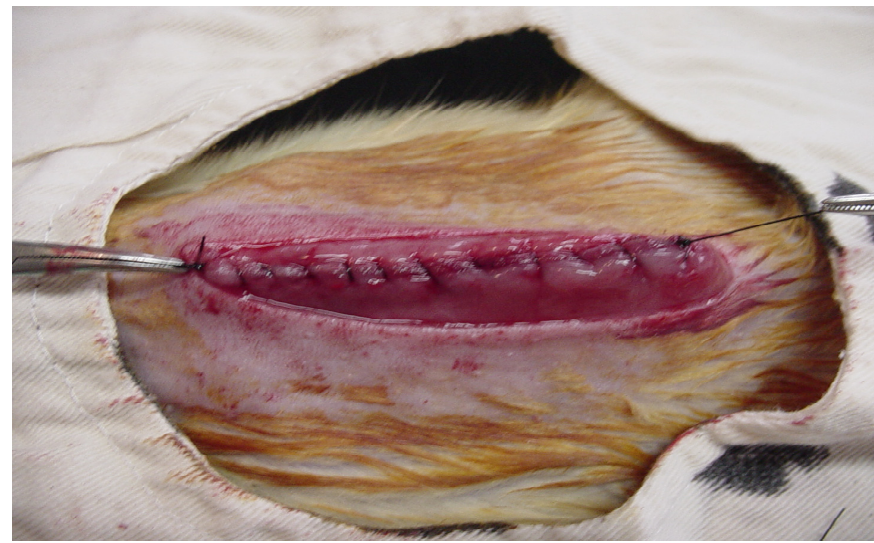

FIGURE 1 - Closure of the aponeurosis using the nylon suture

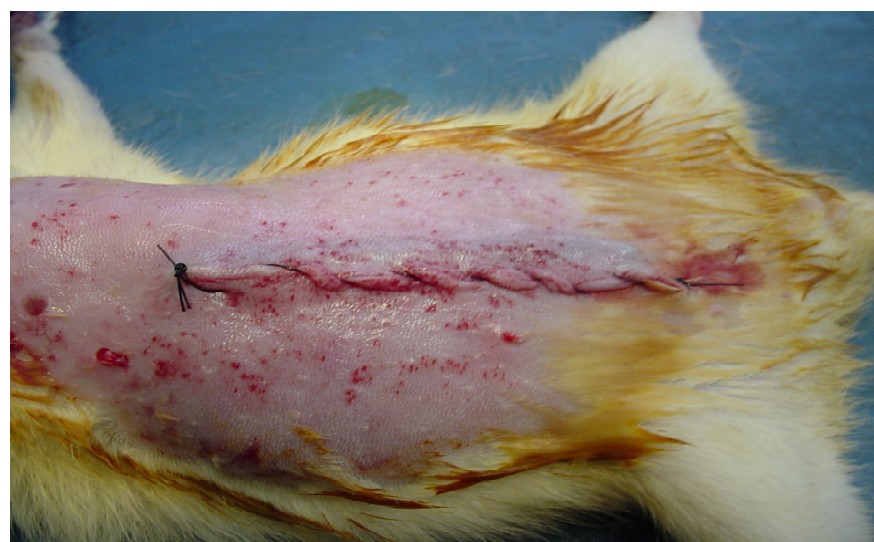

FIGURE 2 - Suture of the skin

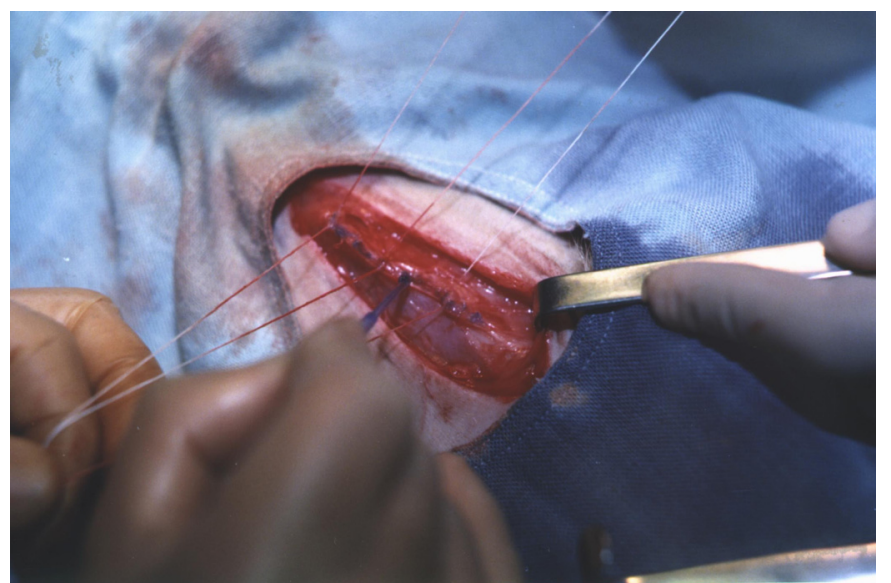

FIGURE 3 - Closure of the aponeurosis using the tissue adhesive
After recovering from anesthesia, the rats were placed in individual cages and had water and food ad libitum $^{12}$.

After surgery, group I and group II animals were divided into subgroups of 11 animals each. They were weighed again and later submitted to anesthesia and reoperation either seven or 14 days after the first surgery ${ }^{2,6}$, following the same procedure previously described. The animals were divided as follows: subgroup IA - suture, 7 days until reoperation; subgroup IB - suture, 14 days until reoperation; subgroup IIA - adhesive, 7 days until reoperation; and subgroup IIB - adhesive, 14 days until reoperation.

During reoperation, the rats were submitted to reopening of the sutured skin and macroscopic examination of the aponeurosis. The macroscopic examination of the aponeurosis was performed to check for the presence of surgical wound infection, wound dehiscence and adhesive residue at the site.

After the macroscopic examination, the animals were sacrificed using a lethal dose of the anesthetic. The tensile strength of the musculoaponeurotic plane was then assessed.

The tensile strength test was performed with a balloon catheter constructed using a surgical glove finger adapted to a $16 \mathrm{~F}$ Foley catheter and connected to a mercury sphygmomanometer (Figure 4). An incision of approximately $0.5 \mathrm{~cm}$ was made in the posterior abdominal wall of each rat. The balloon was placed inside the abdominal cavity and the catheter was fixed to the skin using a purse-string suture with 2-0 cotton suture. The sphygmomanometer was connected to the balloon catheter, which was inflated slowly and steadily until the rupture of the abdominal wall and exposure of the balloon through the incision. The pressure required for rupture, expressed in millimeters of mercury, was recorded ${ }^{3,16}$.

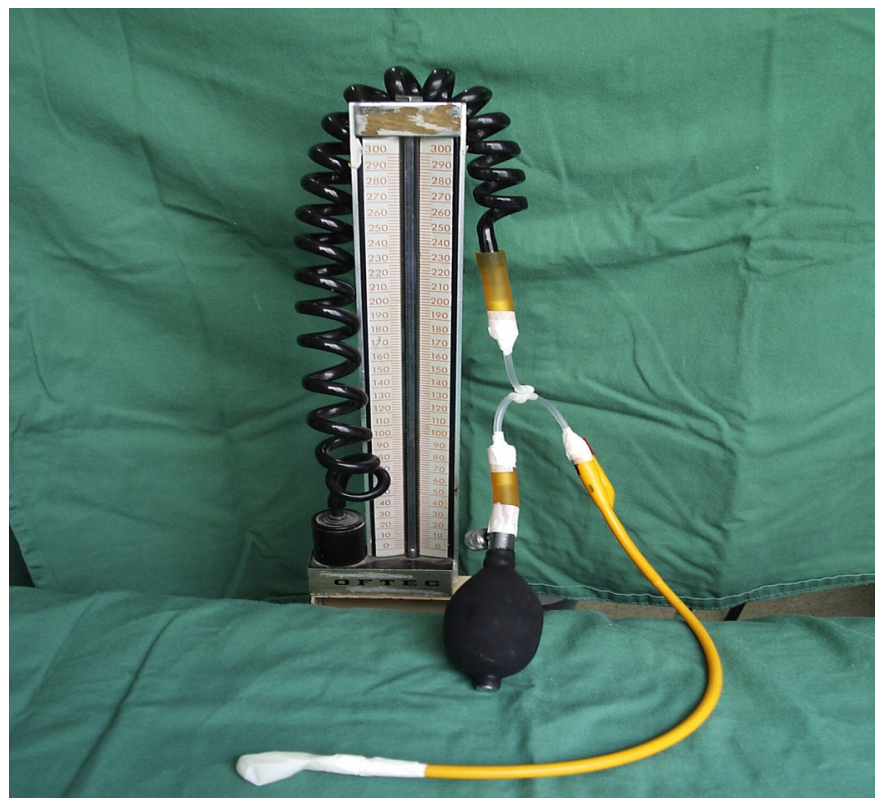

FIGURE 4 - Apparatus used to assess tensile strength 
The wound edges were resected and examined under an optical microscope $e^{3}$. For the histological examination, the samples were embedded in paraffin and sliced into sections which were stained with hematoxylin and eosin.

The histological sections were evaluated according to the following parameters: necrosis; presence of inflammatory cells and their prevalence; neovascularization; vascular congestion; edema; collagenization; foreign body reaction and microabscesses. For the analysis of the results obtained, each parameter received a score as follows ${ }^{17}$.

1 - Necrosis: present $=0$; absent $=1$

2 - Inflammatory cells: prevalence of polymorphonuclear leukocytes $=0$; prevalence of mononuclear leukocytes $=1$

3 - Neovascularization: mild $=1$; moderate $=2$; increased $=3$; absent $=0$

4 - Vascular congestion: mild $=2$; moderate $=1$; severe $=0$; absent $=3$

5 - Edema: mild $=2 ;$ moderate $=1 ;$ severe $=0 ;$ absent $=3$

6 - Collagenization: mild $=1$; moderate $=2$; increased $=3$; absent $=0$

7 - Foreign body reaction: mild $=1 ;$ moderate $=2$; strong $=3$; absent $=0$

8 - Microabscesses: present $=0 ;$ absent $=1$

Total scores ranged from 0 to 18 . Thus, the higher the score the better the healing, as demonstrated by Greca et al. ${ }^{18}$. The scores obtained were used to statistically compare the quality of the healing process between groups.
Descriptive analysis was divided into two parts: analysis of the differences between groups for each variable and analysis of the association between scores and tensile strength with the animals' weights and the time taken to close the wound.

Inferential analysis was divided according to the variables of comparison: weight, the time taken to close the wound, scores and tensile strength. For the comparison of weights, ANOVA with two grouping factors (days until reoperation and group) and one repeated factor (preoperative weight and prereoperative weight) was used. For the comparison of the time required to close the surgical wound, as well as of the scores, two-factor ANOVA was used. Finally, for the comparison of tensile strengths, the Cox proportional hazards model was used.

Bonferroni corrections were not made because we assumed that the comparison of weights and time taken for wound closure were only made to confirm the inexistence of a possible study bias. Even considering the existence of two variables of direct interest, scores and tensile strength, we decided not to make any type of correction, since the analysis was performed in a different manner for each of the variables. The level of significance was set at $p<0.05$ for all the statistical analyses performed.

\section{Results}

\section{Weight analysis}

Table 1 shows the measured weights of the animals. No significant difference is observed between the four subgroups, indicating that the sample is homogeneous.

TABLE 1 - Measured weights (g)

\begin{tabular}{|c|c|c|c|c|c|c|c|c|c|c|}
\hline \multirow{3}{*}{$\begin{array}{l}\text { Days until } \\
\text { reoperation }\end{array}$} & \multirow{3}{*}{$\begin{array}{l}\text { Statistical } \\
\text { measures }\end{array}$} & \multicolumn{3}{|c|}{ Preoperative weight } & \multicolumn{3}{|c|}{ Pre-reoperative weight } & \multicolumn{3}{|c|}{ Weight difference } \\
\hline & & \multicolumn{2}{|c|}{ Group } & \multirow{2}{*}{ Total } & \multirow{2}{*}{\multicolumn{2}{|c|}{$\frac{\text { Group }}{\text { Suture Adhesive }}$}} & \multirow{2}{*}{ Total } & \multicolumn{2}{|c|}{ Group } & \multirow{2}{*}{ - Total } \\
\hline & & Suture & Adhesive & & & & & Suture & Adhesive & \\
\hline \multirow[t]{6}{*}{7 days } & $\mathrm{n}$ & 11 & 11 & 22 & 11 & 11 & 22 & 11 & 11 & 22 \\
\hline & Mean & 310 & 316 & 313 & 290 & 296 & 293 & -20 & -20 & -20 \\
\hline & $\begin{array}{l}\text { Standard } \\
\text { deviation }\end{array}$ & 35 & 40 & 37 & 41 & 35 & 37 & 20 & 17 & 18 \\
\hline & Median & 310 & 320 & 310 & 290 & 290 & 290 & -10 & -30 & -10 \\
\hline & Minimum & 260 & 260 & 260 & 250 & 230 & 230 & -60 & -50 & -60 \\
\hline & Maximum & 400 & 400 & 400 & 390 & 370 & 390 & 0 & 0 & 0 \\
\hline \multirow[t]{6}{*}{14 days } & $\mathrm{n}$ & 11 & 11 & 22 & 11 & 11 & 22 & 11 & 11 & 22 \\
\hline & Mean & 332 & 316 & 324 & 309 & 301 & 305 & -23 & -15 & -19 \\
\hline & $\begin{array}{l}\text { Standard } \\
\text { deviation }\end{array}$ & 52 & 43 & 47 & 55 & 43 & 48 & 26 & 20 & 23 \\
\hline & Median & 350 & 330 & 330 & 300 & 300 & 300 & -20 & -20 & -20 \\
\hline & Minimum & 250 & 250 & 250 & 240 & 210 & 210 & -70 & -40 & -70 \\
\hline & Maximum & 400 & 400 & 400 & 400 & 380 & 400 & 20 & 30 & 30 \\
\hline \multirow[t]{6}{*}{ Total } & $n$ & 22 & 22 & 44 & 22 & 22 & 44 & 22 & 22 & 44 \\
\hline & Mean & 321 & 316 & 319 & 300 & 299 & 299 & -21 & -18 & -20 \\
\hline & $\begin{array}{l}\text { Standard } \\
\text { deviation }\end{array}$ & 45 & 41 & 42 & 48 & 38 & 43 & 23 & 18 & 20 \\
\hline & Median & 310 & 325 & 310 & 290 & 300 & 295 & -10 & -20 & -15 \\
\hline & Minimum & 250 & 250 & 250 & 240 & 210 & 210 & -70 & -50 & -70 \\
\hline & Maximum & 400 & 400 & 400 & 400 & 380 & 400 & 20 & 30 & 30 \\
\hline
\end{tabular}


An average weight loss of approximately $20 \mathrm{~g}$ was observed between the weights measured prior to the first and second surgical procedures. This created a variable that was called "weight difference", which was statistically significant according to ANOVA $(\mathrm{p}=0.001)$, as seen in Tables 2 and 3. However, no significant difference between subgroups (suture or adhesive, seven or 14 days until reoperation) was observed when this variable was considered. Thus, the weight loss was an independent variation, unrelated to the method for wound closure or the number of days until reoperation (Table 2).
TABLE 2 - Repeated-measures ANOVA with two grouping factors for the comparison of weight

\begin{tabular}{lc}
\hline \multicolumn{1}{c}{ Factors } & $p$ \\
\hline Weight difference & 0.001 \\
Weight difference * Group $^{*}$ & 0.567 \\
Weight difference * Days until reoperation & 0.886 \\
Weight difference * Group * Days until & \\
reoperation & 0.567 \\
\hline
\end{tabular}

TABLE 3 - Mean difference between pre-reoperative and preoperative weights

\begin{tabular}{ccccccc}
\hline \multirow{2}{*}{ Variable } & $\begin{array}{c}\text { Mean } \\
\text { difference }\end{array}$ & $\begin{array}{c}\text { Standard } \\
\text { error }\end{array}$ & $p$ & \multicolumn{2}{c}{ Confidence interval (95\%) } \\
\cline { 6 - 6 } Weight difference & -19.6 & 3.15 & 0.001 & & Lower limit & Upper limit \\
\hline
\end{tabular}

Analysis of the time taken to close the surgical wound

Table 4 shows the time taken to close the aponeurosis. The mean time taken to close the surgical wound was not significantly different when we compared animals that were reoperated on seven days after the first surgery with those which were reoperated on 14 days after the first surgery, whether they belonged to the suture or adhesive groups.

It was clear, however, that wound closure time was significantly shorter for the tissue adhesive group, when compared with the suture group. The maximum amount of time spent on wound closure was 58 seconds when the tissue adhesive was used. On the other hand, the minimum amount of time spent on wound closure was 86 seconds when the nylon suture was used. It took on average 84 seconds longer to close the surgical wound using the nylon suture than using the adhesive, which showed significant difference between both groups (Tables 5 and 6).

TABLE 5 - Two-factor ANOVA for the comparison of the time spent on wound closure

\begin{tabular}{cc}
\hline Factors & $\mathrm{p}$ \\
\hline Group & 0.001 \\
Days until reoperation & 0.589 \\
Group*Days until reoperation & 0.134 \\
\hline
\end{tabular}

TABLE 4 - Time spent on wound closure (in seconds)

\begin{tabular}{|c|c|c|c|c|}
\hline \multirow{3}{*}{$\begin{array}{l}\text { Days until } \\
\text { reoperation }\end{array}$} & \multirow{3}{*}{$\begin{array}{l}\text { Statistical } \\
\text { measures }\end{array}$} & \multicolumn{3}{|c|}{ Time spent on wound closure } \\
\hline & & \multicolumn{2}{|c|}{ Group } & \multirow{2}{*}{ Tota } \\
\hline & & Suture & Adhesive & \\
\hline \multirow[t]{6}{*}{7 days } & $\mathrm{n}$ & 11 & 11 & 22 \\
\hline & Mean & 115 & 24 & 69 \\
\hline & Standard & 16 & 8 & 48 \\
\hline & Median & 112 & 21 & 64.5 \\
\hline & Minimum & 91 & 15 & 15 \\
\hline & Maximum & 145 & 38 & 145 \\
\hline \multirow[t]{6}{*}{14 days } & $\mathrm{n}$ & 11 & 11 & 22 \\
\hline & Mean & 110 & 33 & 72 \\
\hline & $\begin{array}{l}\text { Standard } \\
\text { deviation }\end{array}$ & 16 & 15 & 43 \\
\hline & Median & 113 & 29 & 72 \\
\hline & Minimum & 86 & 10 & 10 \\
\hline & Maximum & 138 & 58 & 138 \\
\hline \multirow[t]{6}{*}{ Total } & $\mathrm{n}$ & 22 & 22 & 44 \\
\hline & Mean & 113 & 28 & 70 \\
\hline & Standard & 16 & 13 & 45 \\
\hline & Median & 112.5 & 26 & 72 \\
\hline & Minimum & 86 & 10 & 10 \\
\hline & Maximum & 145 & 58 & 145 \\
\hline
\end{tabular}

TABLE 6 - Mean difference between the suture and tissue adhesive groups regarding the time taken to close the surgical wound

\begin{tabular}{|c|c|c|c|c|c|}
\hline \multirow{2}{*}{$\begin{array}{l}\text { Time spent on } \\
\text { wound closure }\end{array}$} & \multirow{2}{*}{ Mean difference } & \multirow{2}{*}{$\begin{array}{l}\text { Standard } \\
\text { error }\end{array}$} & \multirow{2}{*}{$p$} & \multicolumn{2}{|c|}{ Confidence interval (95\%) } \\
\hline & & & & Lower limit & Upper limit \\
\hline Suture - Adhesive & 84 & 4 & 0.001 & 76 & 93 \\
\hline
\end{tabular}




\section{Macroscopic examination}

With regard to the presence of infection, the examination of the outer and inner surfaces of the rats' surgical wounds revealed a small abscess and minor wound dehiscence in one animal from subgroup IIB (adhesive, reoperation after 14 days). Fisher's test showed no statistical significance for this result.

\section{Analysis of tensile strength}

The tensile strength of the aponeurosis after closure was tested in all animals. Wound dehiscence was observed in all animals. The values obtained for tensile strength are shown in Table 7.

TABLE 7 - Tensile strength values ( $\mathrm{mm} \mathrm{Hg}$ )

\begin{tabular}{|c|c|c|c|c|}
\hline \multirow{3}{*}{$\begin{array}{l}\text { Days until } \\
\text { reoperation }\end{array}$} & \multirow{3}{*}{ Statistical measures } & \multicolumn{3}{|c|}{ Tensile strength } \\
\hline & & \multicolumn{2}{|c|}{ Group } & \multirow{2}{*}{ Tota } \\
\hline & & Suture & Adhesive & \\
\hline \multirow[t]{6}{*}{7 days } & $\mathrm{n}$ & 11 & 11 & 22 \\
\hline & Mean & 264 & 259 & 261 \\
\hline & Standard deviation & 28 & 32 & 29 \\
\hline & Median & 270 & 250 & 265 \\
\hline & Minimum & 230 & 220 & 220 \\
\hline & Maximum & 300 & 300 & 300 \\
\hline \multirow[t]{6}{*}{14 days } & $\mathrm{n}$ & 11 & 11 & 22 \\
\hline & Mean & 254 & 297 & 275 \\
\hline & Standard deviation & 42 & 6 & 37 \\
\hline & Median & 270 & 300 & 290 \\
\hline & Minimum & 160 & 280 & 160 \\
\hline & Maximum & 300 & 300 & 300 \\
\hline \multirow[t]{6}{*}{ Total } & $\mathrm{n}$ & 22 & 22 & 44 \\
\hline & Mean & 259 & 278 & 268 \\
\hline & Standard deviation & 35 & 30 & 34 \\
\hline & Median & 270 & 300 & 275 \\
\hline & Minimum & 160 & 220 & 160 \\
\hline & Maximum & 300 & 300 & 300 \\
\hline
\end{tabular}

The Kaplan-Meier survival curves show that the best results were observed in animals from subgroup IIB (adhesive, reoperation after 14 days) (Figure 5).

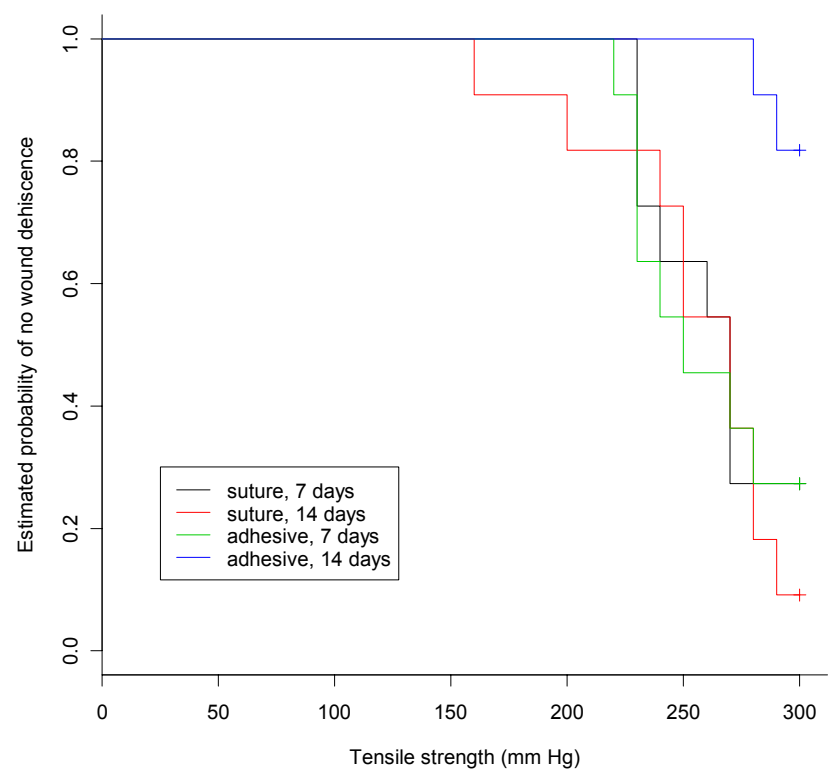

FIGURE 5 - Kaplan-Meier survival curves

With regard to the risk of wound dehiscence over time, a significant difference was observed between the animals of subgroup IIB and those of the remaining subgroups. The risk of dehiscence in the animals of the remaining subgroups was seven times higher than the risk of dehiscence in the animals of subgroup IIB (adhesive, reoperation after 14 days) (Table 8).

TABLE 8 - Results of the Cox proportional hazards model adjustment

\begin{tabular}{ccccccc}
\hline Subgroups & Coefficient & $\begin{array}{c}\text { Standard } \\
\text { error }\end{array}$ & $p$ & $\mathrm{RR}^{*}$ & \multicolumn{2}{c}{ Confidence interval for RR (95\%) } \\
& Adhesive, & & & Lower limit & Upper limit \\
$\begin{array}{c}\text { seven days } \\
\begin{array}{c}\text { Suture, } 14 \\
\text { days }\end{array}\end{array}$ & 0.052 & 0.501 & 0.920 & 1.050 & 0.395 & 2.810 \\
$\begin{array}{c}\text { Adhesive, } 14 \\
\text { days }\end{array}$ & -2.040 & 0.476 & 0.610 & 1.270 & 0.502 & 3.237 \\
\hline
\end{tabular}

*RR: Relative Risk 
Figure 6 shows the dispersion between tensile strength and the variables weight and time to close the surgical wound.
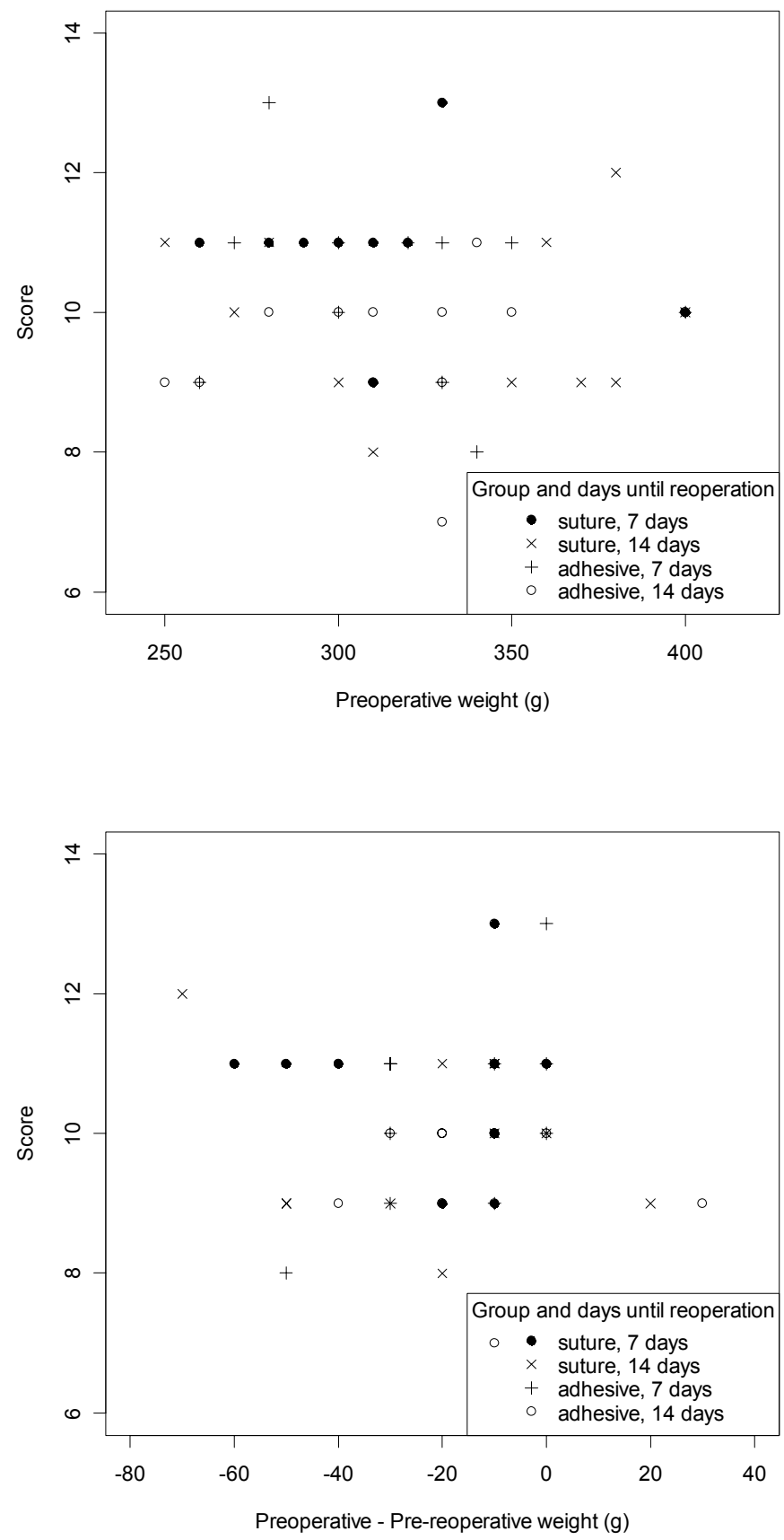

We can observe that there is no evidence of association between the variables considered.
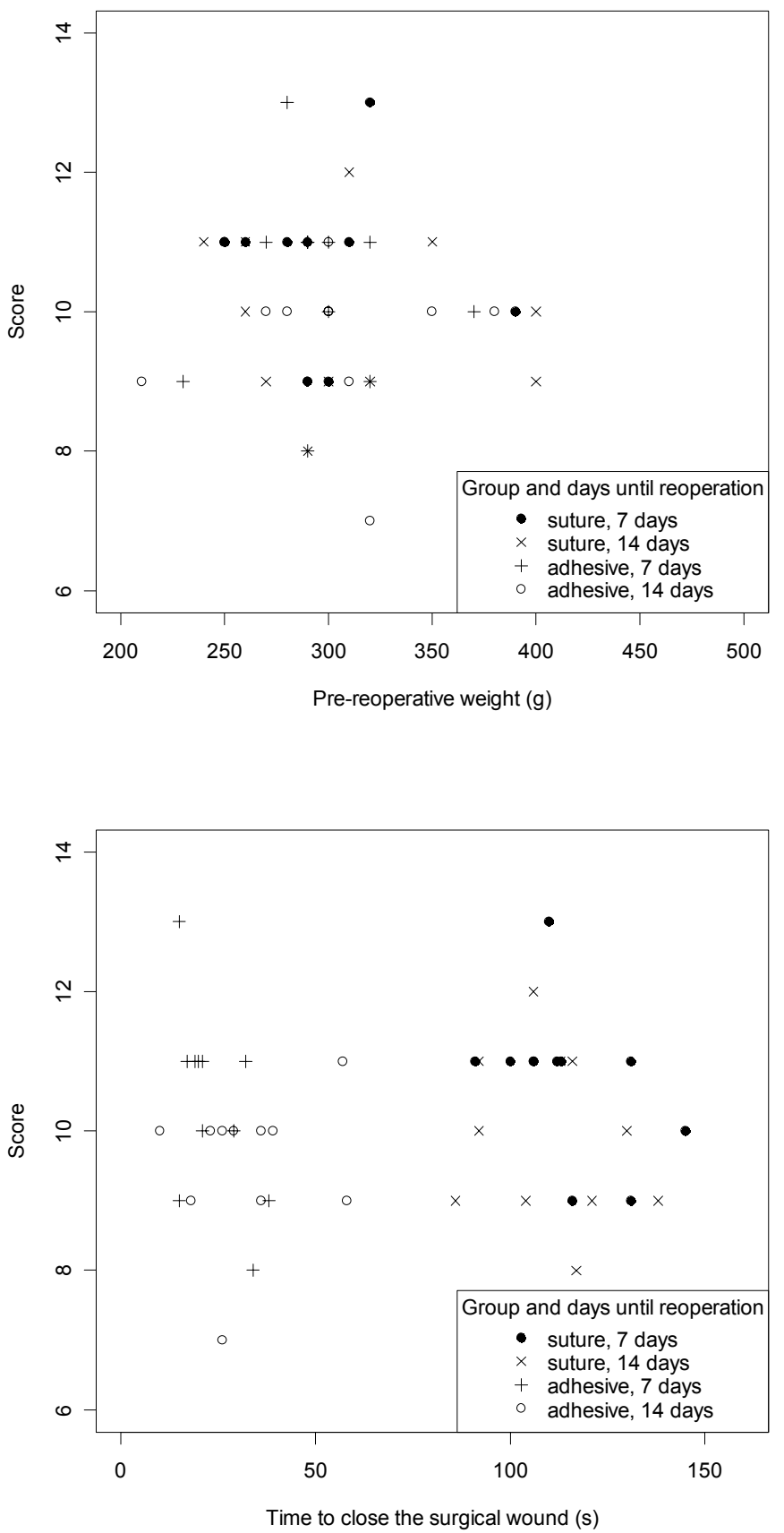

FIGURE 6 - Graphs showing the dispersion between tensile strength and the following variables: preoperative weight, pre-reoperative weight, weight difference, and time to close the surgical wound 


\section{Histological evaluation}

Table 9 shows the scores obtained. No significant difference was observed between groups.

When the scores of the suture and adhesive groups were compared, the analysis of variance showed no significant difference, as seen in Tables 10 and 11. However, a significant difference was observed when the number of days until reoperation was considered (seven or 14 days). The scores of the subgroups reoperated on after 14 days were on average 0.82 lower than those of the subgroups reoperated on after 7 days (Tables 10 to 12 ).
TABLE 9 - Scores obtained

\begin{tabular}{|c|c|c|c|c|}
\hline \multirow{3}{*}{$\begin{array}{l}\text { Days until } \\
\text { reoperation }\end{array}$} & \multirow{3}{*}{$\begin{array}{l}\text { Statistical } \\
\text { measures }\end{array}$} & \multicolumn{3}{|c|}{ Score } \\
\hline & & \multicolumn{2}{|c|}{ Group } & \multirow{2}{*}{ Tota } \\
\hline & & Suture & Adhesive & \\
\hline \multirow[t]{6}{*}{7 days } & $\mathrm{n}$ & 11 & 11 & 22 \\
\hline & Mean & 11 & 10 & 11 \\
\hline & Standard deviation & 1 & 1 & 1 \\
\hline & Median & 11 & 11 & 11 \\
\hline & Minimum & 9 & 8 & 8 \\
\hline & Maximum & 13 & 13 & 13 \\
\hline \multirow[t]{6}{*}{14 days } & $\mathrm{n}$ & 11 & 11 & 22 \\
\hline & Mean & 10 & 10 & 10 \\
\hline & Standard deviation & 1 & 1 & 1 \\
\hline & Median & 10 & 10 & 10 \\
\hline & Minimum & 8 & 7 & 7 \\
\hline & Maximum & 12 & 11 & 12 \\
\hline \multirow[t]{6}{*}{ Total } & $\mathrm{n}$ & 22 & 22 & 44 \\
\hline & Mean & 10 & 10 & 10 \\
\hline & Standard deviation & 1 & 1 & 1 \\
\hline & Median & 11 & 10 & 10 \\
\hline & Minimum & 8 & 7 & 7 \\
\hline & Maximum & 13 & 13 & 13 \\
\hline
\end{tabular}

TABLE 10 - Two-factor ANOVA for the comparison of scores

\begin{tabular}{cc}
\hline Variable & $\mathrm{p}$ \\
\hline Group & 0.316 \\
Days until reoperation & 0.028 \\
Group* Days until reoperation & $>0.999$ \\
\hline
\end{tabular}

TABLE 11 - Mean difference between the scores of the suture and adhesive groups

\begin{tabular}{|c|c|c|c|c|c|}
\hline \multirow{2}{*}{ Score } & \multirow{2}{*}{ Mean difference } & \multirow{2}{*}{$\begin{array}{c}\text { Standard } \\
\text { error }\end{array}$} & \multirow[b]{2}{*}{$p$} & \multicolumn{2}{|c|}{ Confidence interval (95\%) } \\
\hline & & & & Lower limit & Upper limit \\
\hline $\begin{array}{l}\text { Suture - } \\
\text { Adhesive }\end{array}$ & 0.36 & 0.36 & 0.316 & -0.36 & 1.09 \\
\hline
\end{tabular}

TABLE 12 - Mean difference in scores between groups of animals reoperated on 14 or seven days after the first surgery

\begin{tabular}{cccccc}
\hline \multirow{2}{*}{ Score } & Mean difference & $\begin{array}{c}\text { Standard } \\
\text { error }\end{array}$ & $p$ & \multicolumn{2}{c}{ Confidence interval $(95 \%)$} \\
\cline { 5 - 6 } 14 days -7 days & -0.82 & 0.36 & 0.028 & -1.54 & Lower limit \\
\hline
\end{tabular}


Figure 7 shows the dispersion between scores and the variables weight and time to close the surgical wound. We can
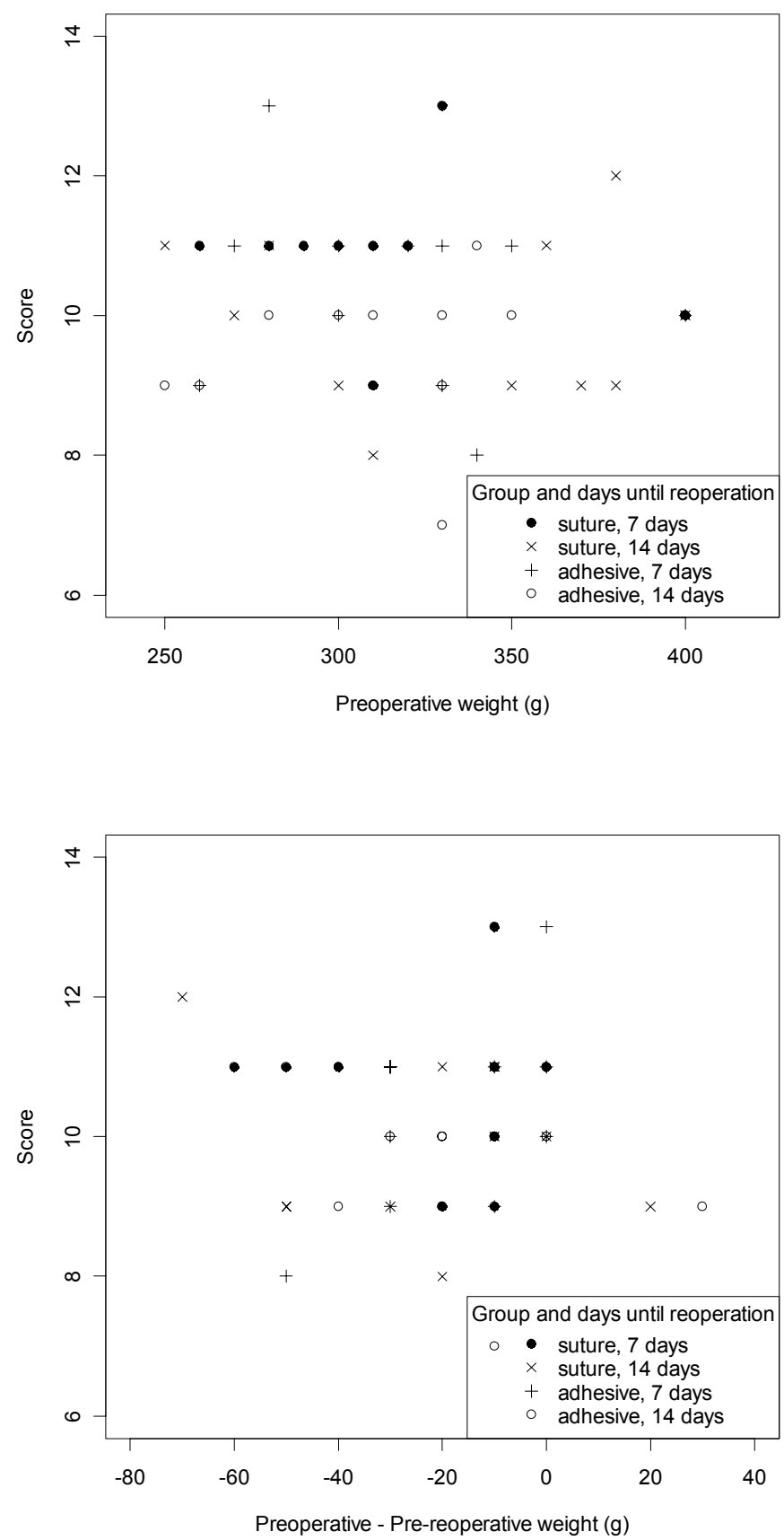

observe that there is no evidence of association between the variables considered.
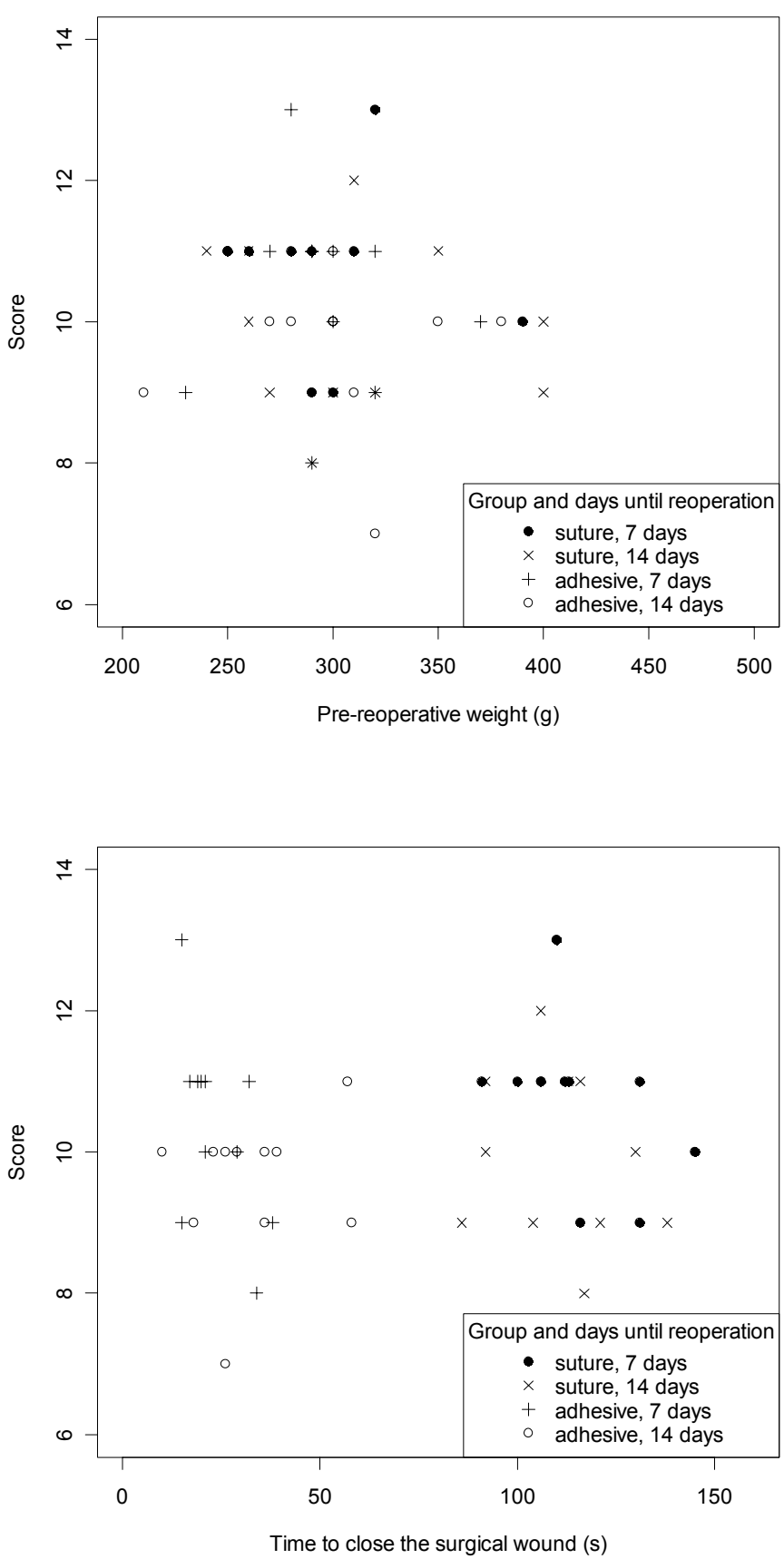

FIGURE 7 - Graphs showing the dispersion between scores and the following variables: preoperative weight, pre-reoperative weight, weight difference, and time to close the surgical wound

\section{Discussion}

The history of surgery shows that the suture material has always been essential to hold the wound edges in place while the healing process takes place ${ }^{18}$.
The healing of the abdominal aponeurosis follows the same principles as those of other mesenchymal tissues; however, the abdominal aponeurosis has limited blood supply and, because of this, limited healing potential ${ }^{19}$. 
Suture closure of wounds is still the most used method of bringing the edges of a surgical wound together. There are various suture materials available, and their use depends on the type of tissue to be sutured ${ }^{18}$.

Cyanoacrylate adhesives have been increasingly used in medicine. Clinical and experimental studies on cyanoacrylates are often found in the literature. Increasingly detailed and sophisticated studies are being carried out, especially in experimental surgery. Over the last three decades, surgeons have actively searched for a liquid substance with adhesive properties, which can be applied to the wound edges, holding them in proximity with minimal interference in the healing process. Tissue adhesives and their various clinical applications are an alternative to suture materials ${ }^{5,10,11,13}$.

Borba et al. ${ }^{11}$ have reported that cyanoacrylates have drawn special attention of researchers because of their low cost and toxicity, good adhesive properties and easy handling.

We decided to conduct the present study because no experimental studies that investigated the use of cyanoacrylate adhesives for the closure of surgical wounds in the abdominal aponeuroses were found in the literature.

The rat was chosen for a number of reasons including easy availability, management and handling, and low cost. In addition, in cases when genetic and physiologic similarity is needed, sample homogeneity is more easily achieved with $\operatorname{rats}^{15,19}$. The rat has been widely used because of the anatomical and biological similarities between its abdominal wall and that of humans; it was, therefore, the right choice for this study ${ }^{6,7}$. Various studies have reported that it is easier to anesthetize and operate on Wistar rats in experimental studies ${ }^{19}$, which corroborates the use of this rat strain in the present study.

Sodium thiopental was used as anesthetic because it produces good muscle relaxation and sedation ${ }^{12}$ and has been widely used in experimental studies. Furthermore, duration of anesthesia with this drug is short (five to 15 minutes) ${ }^{15}$ and the cost is low. The drug was administered intraperitoneally because it was easier and would not interfere with the procedure. The dose given was $50 \mathrm{mg} / \mathrm{Kg}$ of body weight, which is in accordance with some studies found in the literature ${ }^{2,6}$.

We chose to perform an abdominal incision because it allows quick entry into the abdominal cavity ${ }^{19}$. A $4 \mathrm{~cm}$ incision was enough to perform the closure of the aponeurosis, as performed by Loureiro et al. ${ }^{6}$ and Fernandez et al. ${ }^{8}$

The suture material chosen for this comparative study was the 3-0 monofilament nylon suture (Mononylon ${ }^{\circledR}$ ), which is a polyamide made from diamine and dicarboxylic acid, industrially produced since $1940^{18}$. Nylon is an inert material, with good tensile strength when placed in aponeuroses, and it has been widely used in daily surgical practice and experimental studies ${ }^{12,18,19}$.

The surgical wound in the aponeurosis was closed using a continuous suture technique, which is quick, easy and widely used in daily surgical practice. The choice between interrupted stitches or continuous suture to close the abdominal wall is controversial ${ }^{2,19,20}$.

Poole ${ }^{20}$ showed in an experimental study that both interrupted and continuous suture techniques were equally safe.
However, shorter time and less material were required when placing continuous sutures. Tognini et $a l^{2}$ have conducted a comparative study in rats and concluded that the abdominal wall showed higher tensile strength when sutured with interrupted stitches than with continuous sutures on the seventh postoperative day. No significant differences, however, were observed between both techniques on the fourteenth postoperative day.

The cyanoacrylate tissue adhesive was used in the present study because we found no studies investigating the use of this adhesive for the closure of surgical wounds and its effects on the healing process of the anterior abdominal wall of rats or any other laboratory animal, despite its use in various medical fields ${ }^{10,11,14}$.

Ideally, when performing wound closure or anastomoses, a sufficient amount of adhesive should be uniformly applied in thin layers, avoiding waste, which frequently occurs when the adhesive is applied in drops ${ }^{5,9}$. According to Baptista Rosas $^{10}$, the difficulty in applying the adhesive was one of its initial disadvantages.

When closing a surgical wound, the tensile strength of the wound edges is the primary concern of a surgeon. This is particularly important in abdominal surgery because of the characteristics of the abdominal wall and viscera. They are both subject to variations in pressure and volume, caused by their constitution and contents. In addition, the abdominal wall is a site that has strong musculature without the protection of bones ${ }^{19}$.

Tensile strength tests or other methods of assessing the tensile strength of the abdominal wall play a fundamental role in studies of the healing of surgical wounds in the abdominal wall ${ }^{6,19}$.

To assess tensile strength, we used the technique developed by Udupa and, Chansouria ${ }^{17}$ and also employed by Lenharo and Mantovani ${ }^{3}$, since access to a testing machine was difficult and expensive. We chose this technique because the equipment and materials needed are cheap and easily obtained, with successful results documented in the literature. The balloon catheter was placed through the rat's posterior abdominal wall, far from the first incision site, so that its intraperitoneal placement would not hinder the strength of the sutured wall ${ }^{3}$.

All microscopic examinations were conducted by the same pathologist, who did not know which group he was examining at the time. Hematoxylin-eosin stain was chosen because, in addition to being widely used in histological studies, it is a simple and cheap staining method, adequate for identifying and quantifying the cellular elements involved in the healing process ${ }^{19}$.

The division of animals into two groups allowed us to assess the healing of the abdominal wall after using two different wound closure techniques. Wound closure was assessed either seven or 14 days after surgery, time necessary for the abdominal wall to close and withstand stress until tissue tensile strength is adequate ${ }^{6}$. It is believed that, until the seventh postoperative day, tensile strength across the wound is almost exclusively maintained by the suture material. Therefore, the tensile strength of the wound depends on the quality of the material used to hold the wound edges in proximity (suture or adhesive). It is expected that between the seventh and fourteenth 
postoperative days, collagen lysis and collagen deposition reach equilibrium. After the eighth day, collagen deposition exceeds collagen lysis, and the relationship between deposition and lysis should stabilize around the fourteenth day. Poole ${ }^{21}$ demonstrated that the intrinsic strength of a surgical wound in the aponeurosis at 14 days corresponds to $80 \%$ of the strength of the surrounding tissue. He concluded that sutures did not contribute to increase the tensile strength at the site after 14 days.

In the present study, all rats were weighed immediately before the first surgery and reoperation. Weight loss occurred in both groups, with an average loss of approximately $20 \mathrm{~g}$, indicating sample homogeneity (Table 1). The results of the ANOVA comparing postoperative and post-reoperative weights (Tables 2 and 3) showed that the only significant variable was "weight difference", which represented the difference between the weights measured immediately before the first and the second surgical procedures $(p=0.001)$. The weight loss observed was not related to the groups studied or the number of days until reoperation (Table 2). It was probably a result of the effects of anesthesia and postoperative metabolic changes, which is in accordance with the observations of Loureiro et al. ${ }^{6}$.

When considering the number of days until reoperation - either seven or 14 days - no significant difference was observed between groups regarding the time taken to close the surgical wound (Table 4). When considering the wound closure method, it took on average 84 seconds longer to close the surgical wound with the nylon suture. Fifty-eight seconds was the longest it took to close the surgical wound using the tissue adhesive, showing a statistically significant difference between the groups (ANOVA; $p=0.001$ ) (Tables 5 and 6). Application of the adhesive in thin layers was quick and easy, which is in accordance with studies found in the literature; it is also an important advantage of this technique over suture closure of wounds ${ }^{10,11}$.

Upon macroscopic examination, only one animal showed surgical wound infection and minor wound dehiscence. According to Fisher's exact test, this finding was not statistically significant; therefore no significant difference between groups was observed with regard to the macroscopic examination. All group II animals showed adhesive residue at the surgical site. This is in accordance with the observations of other authors, who also found adhesive residue at the surgical site? Cyanoacrylate adhesives are absorbable and eliminated in urine and feces. The time it takes for the adhesive to be absorbed varies widely. It depends not only on the lateral chain of the product, but also on the organs to which it is applied $d^{5,9,10}$.

When tensile strength was compared within the same group (Table 7), group IIB (adhesive, 14 days until reoperation) showed the best results (Figure 1). When both groups were compared (suture and adhesive), we observed that the risk of wound dehiscence over time was seven times lower for animals of group IIB, and this difference was statistically significant between groups (Table 8). This is not in accordance with the results of other studies that compared different types of suture of the aponeurosis seven and 14 days after the procedure. These studies found no significant difference between sutures 14 days after surgery ${ }^{2,6,7,20}$. The average weight loss of $20 \mathrm{~g}$ was not di- rectly related to the tensile strength values observed (Figure 2).

The use of scores, as recommended by Greca et al. ${ }^{17}$, is an interesting method of evaluation using histological parameters. A set of numerical values ranging from 0 to 3 is attributed to each histological pattern; the higher the score the better the healing. The analysis of the parameters performed by an experienced examiner, who does not know the study group to which the specimen belongs, reduces the subjectivity of the histological examination. The scores are shown in Table 9. The ANOVA revealed no significant difference between the suture and adhesive groups when the scores were compared, i.e. the healing process was similar in both groups (Tables 10 and 11). The scores obtained 14 days after the first surgery were on average 0.82 lower than those obtained seven days after surgery, showing a statistically significant difference between groups $(p=0.028)$ (Tables 10 and 12). Although the "weight difference" variable was statistically significant and the mean scores were lower 14 days after the first surgery, the graphs of dispersion showed no evidence of association between scores and weight, i.e. the weight loss did not affect the healing process (Figure 3 ). In addition, although the scores were significantly lower for the animals that were reoperated on 14 days after the first surgery, higher tensile strength was observed in group IIB animals (adhesive, 14 days).

Currently, adhesives are not considered adequate substitutes for sutures with regard to tensile strength. They nevertheless play an important supporting role in certain wound closure techniques, and are sometimes preferred over suture when dealing with special types of tissue $e^{4,5,11,18}$.

Baptista Rosas ${ }^{10}$ reported that adhesives will be more frequently and commonly used in surgery with the passing of time.

Based on the results of this study, we believe that more studies should be carried out to investigate the use of adhesives and their effects on the healing of the aponeurosis, proposing changes that might improve their biological and clinical behavior, so that they can become an effective alternative to sutures for the closure of both surgical and non-surgical wounds.

\section{Conclusions}

The morphological study of the healing process of the aponeurosis of the anterior abdominal wall of rats revealed no significant difference between the two materials used for wound closure, namely 3-0 monofilament nylon suture and N-butyl-2cyanoacrylate, a tissue adhesive. However, wound closure using the adhesive was faster, and a higher tensile strength was observed in the adhesive group submitted to reoperation 14 days after the first surgery. 


\section{References}

1. Brenda E, Marques A, Saldiva PHN, Davini MC, Pereira MD, Minami E, Ferreira MC. Análise do teor de colágeno e resistência tênsil da cicatriz de aponeurose: estudo experimental em suínos. Rev Bras Cir. 1997;87(6):263-72.

2. Tognini JRF, Goldenberg S, Naressse LC, Simões MJ, Alves FLG, Magalhães AM. Estudo comparativo entre sutura contínua e a com pontos separados na parede abdominal de ratos. Acta Cir Bras. 1997;12(4):249-54.

3. Lenharo S, Mantovani M. Estudo comparativo do fechamento da incisão mediana abdominal por planos e com uso de pontos subtotais e tela de poliglactina 910, em ratos. Acta Cir Bras. 1998;13(2):100-5.

4. Souza M, Fagundes DJ, Gomes PO, Ascenção A, Guimarães CA, Mendonça Júnior IT, Guimarães AC, Martins VL. Fios de sutura: uma revisão histórica. Rev Ciênc Biol Saúde. 2001;2(1):98-102.

5. Fagundes DJ, Taha MO, Rivoire HC. Adesivos cirúrgicos: revisão e atualização. JBM. 2002;82(3):101-3.

6. Loureiro VM, Fagundes DJ, Taha MO. Síntese da parede abdominal: avaliação de dois tipos de sutura contínua em ratos. Acta Cir Bras. 2003;18(3):238-44.

7. Meeks GR, Nelson KC, Byars RW. Wound strenght in abdominal incisions: a comparison of two continous mass closure techniques in rats. Am J Obstet Gynecol. 1995; 173(6):1676-83.

8. Fernandez PM, Martins JL, Novo NF, Gomes PO, Goldenberg S. Estudo comparativo da resistência à tração das cicatrizes nas laparotomias longitudinais e transversais em ratos. Acta Cir Bras. 1996;11(3):133-7.

9. Cunha GEB. Contribuição ao estudo das reconstituições do trânsito intestinal sem sutura empregando o adesivo 2-butil-cianoacrilato [tese]. Niterói: Universidade Federal Fluminense; 1976.

10. Baptista Rosas RC. Los cianoacrilatos en cirurgia. Rev Sanid Milit Mex. 1995;49(3):55-8.
11. Borba CC, Roubaud Neto E, Val RDLR do, Borba Júnior CO, Soufen MA, Francisco Neto A, Sakotani AY. Uso do cianoacrilato na síntese da pele de ratos: trabalho de pesquisa experimental. Acta Cir Bras. 2000;15(1):48-54.

12. Fontes CER, Taha MO, Fagundes DJ, Ferreira MV, Prado Filho OR, Mardegan MJ. Estudo comparativo do uso de cola de fibrina e cianoacrilato em ferimento de fígado de rato. Acta Cir Bras. 2004;19(1):37-42.

13. Pires MSM. Comparação histológica entre cola à base de gelatina, resorcina e formaldeído (GRF), fio de sutura mononylon ${ }^{\circledR}$ e etilcianoacrilato na síntese de ferimentos cirúrgicos produzidos em dorso de ratos [tese]. Porto Alegre: Pontifícia Universidade Católica do Rio Grande do Sul; 2002.

14. Helbling C, Schlumpf R. Sutureless Lichtenstein: first results of a prospective randomized clinical trial. Hernia. 2003;7(2):80-4.

15. Schanaider A, Silva PC. Uso de animais em cirurgia experimental. Acta Cir Bras.2004;19(4):441-7.

16. Udupa KN, Chansouria JPN. Studies on wound healing: pattern of healing in different abdominal incision. Ind Jour Med Res. 1969;57(3):434-41.

17. Greca FH, Biondo-Simões MLP, Paula JB de, Noronha L de, Ferreira da Cunha LS, Baggio PV, Bittencourt FO. Correlação entre o fluxo sanguíneo intestinal e a cicatrização de anastomoses colônicas: estudo experimental em cães. Acta Cir Bras. 2000;15(supl 3):88-94.

18. Fagundes DJ, Kharmandayan P. O fio cirúrgico. Acta Cir Bras. 1991;6(4):177-81.

19. Nunes Júnior JAT. Avaliação do efeito do extrato hidroalcoólico de Schinus terebinthifolius Raddi (aroeira) no processo de cicatrização da linha alba de ratos [tese]. Curitiba: Universidade Federal do Paraná; 2003.

20. Poole GV Jr. Mechanical factors in abdominal wound closure: the prevention of fascial dehiscence. Surgery. 1985;97:631-9.

Conflict of interest: none Financial source: none

\section{Correspondence:}

Carlos Augusto Marques Batista

Rua Antonio Stivanin, 315

27.600-000 Valença - RJ Brazil

cambatista@uol.com.br

Received: January 18, 2008

Review: February 14, 2008

Accepted: April 16, 2008

\section{How to cite this article}

Batista CAM, Colleoni Neto R, Lopes Filho GJ. Comparative study of the healing process of the aponeurosis of the anterior abdominal wall of rats after wound closure using 3-0 nylon suture and N-butil-2-cyanoacrylate tissue adhesive. Acta Cir Bras. [serial on the Internet] 2008 July-Aug;23(4). Available from URL: http://www.scielo.br/acb 